\title{
Mythological Beings Based on Mammoths
}

\author{
Petr Jandáček ${ }^{1}$ \\ ${ }^{1} 127$ La Senda Rd. (Los Alamos), White Rock, New Mexico 87547, USA \\ Correspondence: Petr Jandacek, 127 La Senda Rd. (Los Alamos), White Rock, New Mexico 87547, USA.
}

Received: November 21, 2017

Accepted: December 8, $2017 \quad$ Available online: January 5, 2018

doi:10.11114/ijsss.v6i2.2915

URL: https://doi.org/10.11114/ijsss.v6i2.2915

\begin{abstract}
Genetics, linguistics, mythology, art, anthropology and other disciplines converge to remind modern humans that much of their belief system harkens back to the hunters of mammoths and related giant fauna. This is manifest in the fact that all across Eurasia the words for the animal elephant are remarkably similar and are ostensibly derived from the onomatopoeic "ZZZAAAN" sound of mammoth trumpeting. In places where memory about mammoths and elephants no longer survives it is perpetuated in mythologies about giants who suck. These beings are described as being wooly, pachyderm, nasal, gigantic, and in other ways remarkably mammoth-like.
\end{abstract}

Keywords: elephant, mammoth, ogre, anthropomorphic giants, creatures with proboscis

\section{Introduction}

Across Africa, America, Asia and Europe there exist substantial similarities in words for the animal - elephant. It is postulated that the onomatopoeic "ZZZAAAN" sound of elephant trumpeting was best preserved in the Mongol word for the animal elephant: zaan. It is further postulated that this became the standard word for the animal mammoth across Eurasia. The Slavic word for elephant is slon and it is reasonable to assume that in Western Europe (west of the Elbe river and west of Trieste) the words for elephant were also some form of slon prior to the installation of the Greek and Latin form: elephant. This theory is supported by the fact that virtually all other languages of Eurasia use some form of

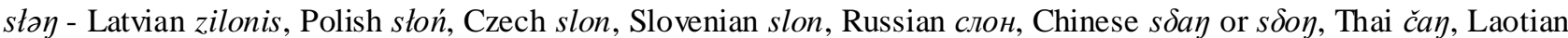
say and there are many other such examples (Jandáček, 2013a,b, 2014, 2017).

It is also interesting that in Celtic languages: Irish, Scottish and Cornish, the word for the nose is srón, which resembles the Slavic word slon. This is in line with the assumption that in Western Europe the aboriginal words for elephant were some form of slon.

Jandáček and Perdih (2017) presented the relation between the words for elephant / mammoth, the (human) DNA Genealogy data and geophysical data. These data indicate that about 68,000 years ago on the East African highlands lived the people having the YChromosome haplogroups A00, A0, A1 a, A1b1, and B. Later they spread across Africa. In the area of Alps and Balkans in Europe, on the other hand, there existed the people having the Y Chromosome haplogroups BT and CT. Their descendants gave later rise to the Y Chromosome haplogroups $\mathrm{C}$ through $\mathrm{T}$. The bearers of these haplogroups spread in time all over the world. This may be the cause of the observed similarities for the word for the animal elephant in a number of different language groups across Africa, America, Asia and Europe. At the time of the global cooling around 68,000 - 62,000 years ago and during the later interstadial there could expand into the lands of the mammoths the people having had the Y Chromosome haplogroups BT and CT as well as their descendants having had the Y Chromosome haplogroups C, D and F. With the subsequent cooling period of about 43,000 - 36,000 years ago and in the later interstadial, the people having Y Chromosome haplogroups BT, CT, C, D, F, G, I, K and P could occupy those lands. During the Last Glacial Maximum the descendants of the haplogroup P (i.e. people having haplogroups Q and R) could expand across Beringia into the Americas.

After conducting research into the words for the animal - elephant around the world (Jandáček, 2013a,b, 2014, 2017) and after linking such words to the human Y Chromosome haplogroups (Jandáček \& Perdih 2017) it seems a logical step to explore mythologies about supernatural beings having names which sound like $s \nmid \jmath \eta$ and who are very anthropomorphic and who look, walk and talk and think like giant humans.

Often these giants have a proboscis or sucking features to suck life out of humans, and often they have only one eye. Among them are: Scandinavian stallo, North American tsonoqua, classical cyclops, Australian papinijuwari. 
Peoples of Eurasia, Beringia and Americas depended on the resources of mammoths and related megafauna for many thousands of years. Flesh, ivories, molars, bones, wool, fats, skins and even dung of elephants was and is valued and traded around the world. Before metals and plastics were used - dental material was treasured. Igloo-like structures made of bone, ivory, mandibles and molars and pachyderm skins provided housing for humans in the old world and new. Shoulder blades of mammoths were used as lids to sarcophagi. Ivory jewelry and wampum adorned the living and the dead. Rendered fats and oils and dung provided fuel for heating and lighting. Long wools provided hawsers, ropes, and yarns.

Mammoths were depicted in petroglyphs and cave paintings. Evidently the heroic scale, human-like anatomy, skull similarities and intelligence inspired awe and attributed to mammoths / elephants supernatural qualities. Such are made conspicuous in this study.

\section{Data}

Mythology about the Elephantine Ogres and Ogresses exists in Lapland, Alaska and North America's northwest coast and even in Australia - beyond the Wallace Line where placental mammals were almost totally absent. Certainly elephants only swam as far towards Australia as Flores Island, Indonesia, where the elephants and Hominids coexisted.

In Arctic Scandinavia, in Lapland there are Mythologies about the Stallo, Figure 1. It is usually a male, very large, ugly, dull witted, sucks out life fluids from human victims though an iron pipe.

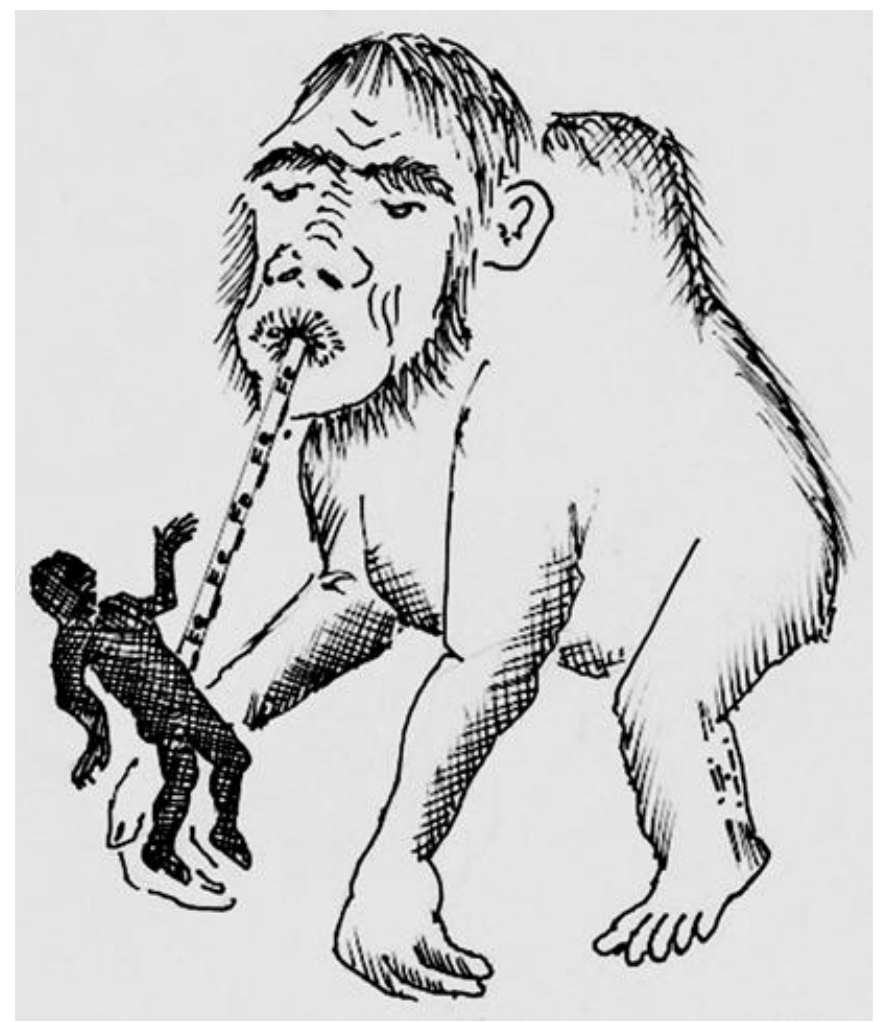

Figure 1. Folklore of the Saami of Lapp-Land: Stallos, a race of Troll-like giants who ate humans or sucked out their strength through an "Iron Pipe" (Lecouteux, 2016;

http://nordligefolk.no/hjem-2/fortellinger-sagn-og-myter/stallo/?lang=en). Drawing by P. Jandáček, Nov. 2017

The Jewish mythological siloni \& silonit of the $4^{\text {th }}$ Plague of Egypt is usually described as insects and sometimes represented as octopus like creatures. Siloni is similar to the Slavic word for elephant - slon, Figure 2. 


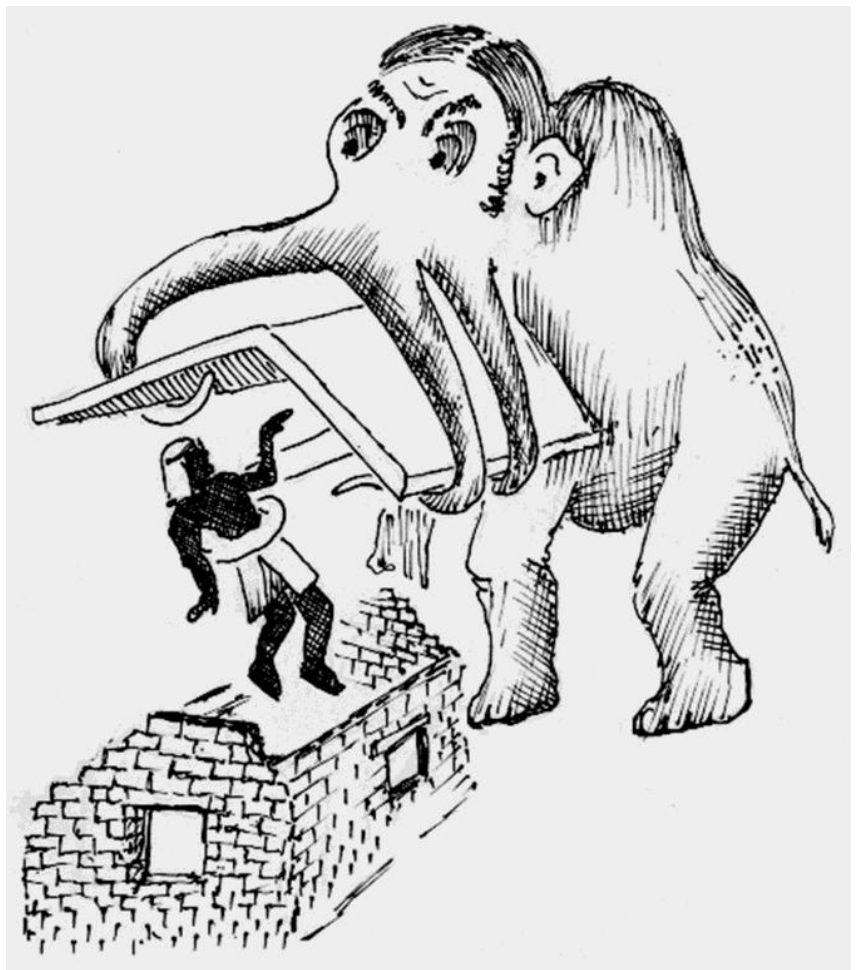

Figure 2. Appearence of the Jewish mythological siloni \& silonit of the $4^{\text {th }}$ Plague of Egypt combined with its similarity to the word slon for elephant. Drawing by P. Jandáček, Nov. 2017

The Mythological Elephantine Ogress of North America, i.e. Amerindian of Western Canada and Alaska is called Tsonoqua also known as Dsonoqua, Dzoonoqua, Dzoonokwa, and many other forms. Dzunukwa, also Tsonoqua, Tsonokwa, is a figure in Kwakwaka'wakw mythology (http://www.revolvy.com/main/index.php?s=Dzunukwa). Boas (Dsonoqua) wrote about Tsonoqua in the American North-West. These Ogres resembled elephants and mammoths, Figure 3. Tsunukwa is the ogress with the basket on the back, a cannibalistic creature, who captures foolish and/or naughty children and keeps them in the backpack.

It is usually a female, very large, small red eyes, pursed lips, hairy, ugly, dull witted, basket on back for foolish or naughty children. She has stones on either side of the mouth (like tusks?), captures children, blows snots at naughty boys, sucks out brains of victims through their ear. May be caught in a pit covered with branches \& soil. When cremated produces clouds of mosquitos. She has sucking anatomical features like an elephant. (Reminiscent of Stallo of the Saami \& other Scandinavians.)

Boas (Dsonoqua) and others annotated mythologies about gigantic ogresses and ogres on the American west coast as well as in Alaska. Such myths extended to the Canadian Rockies as well as to Siberia. Other anthropologists wrote about similar mythological beings in the oral traditions of the Saami living in Lapland of Scandinavia. Ancient Greek legends deal with one eyed giants named Cyclops. Similar one-eyed giants in Australia are called Papinijuwari.

Common clusters of features and reputed behavior of such monsers includes:

1. They are gigantic.

2. Often female, but can be male.

3. Almost blind, with tiny eyes.

4. Frequently with only one eye - in the middle of the forehead.

5. Very hairy - wooly like a mammoth.

6. They have an anatomical feature with which to suck out brains or blood.

7. They squirt fluids from their nose - blow snots and mucus at boys.

8. They have pachyderm-like arrow-resistant skin.

9. They can be trapped in pits camouflaged by branches and soil.

10 . They produce whistling or trumpeting calls. 
11. Females have large, pendulous breasts located between front limbs.

12. They have a Rucksack type baskets on their backs.

13. They grow "stones" (like tusks) from their cheeks.

14. Beak-like noses or mouths are described on such cannibals.

15. They are prone to doze off - drowsy or even catatonic.

16. They have combination of human and animal features.

17. They travel great distances for water.

18. Tsonoquas have magic and treasures and can resurrect from dead.

19. Tsonoquas are described as old, fat, ugly hags.

20. They have a split personality (part human-part beast).

21. They sit like humans.

22. In Siberia Chukchees and Koriaks have similar myths to those in Canada and Alaska.

23. Mongol-Turkic tales of monstrous women are very similar to those of Bella Coola Amerindians. Both describe a female monster with a long snout, which she inserts in ears of humans and sucks out their brains.

24. These monsters often reincarnate into clouds of mosquitos - especially if they are cremated.

The reportage about these ogresses, ogres and other gigantic monsters leads one to conclude that such are oral traditions transmitted from the Upper Paleolithic. They are thinly veiled stories about mammoths and their relatives. Over the millennia the strictly vegetarian giants were retold as monsters with appetite for brains, blood and other humors. It is surprising that Boas and others did not link such mythologies more to the ancestral memories of mammoths.



Figure 3. Tsonoqua, the Amerindian Ogress of Western Canada and Alaska, which carries off naughty and foolish children in her Rucksack-like basket. Drawing by P. Jandáček, Nov. 2017, based on Boas's (Dsonoqua) descriptions

Stallo, Tsonoqua, and Tsonerhwow all have phonemic clusters, which resemble the Slavic word for elephant: slon. An interesting fact is also that some names sound like the Russian word for female elephant $=$ слониха $>$ tслониsquаw (Sloní Squaw?).

On the other hand, the ancestral memory of Elephants superimposed upon giant marsupials was sufficient to create One Eyed Cyclops-Like Mythology in Australia among Australian Aborigines, the Papinijuwari (Mudrooroo, 1994), Figure 
4. The Papinijuwari of Australia has like the Cyclops only a single eye in the center of forehead. Lives in a hut in the sky near the horizon. Carries a torch and a war club. It sucks blood (like mosquito) from dead and sick people. It sucks out life from sick humans. Finally it enters through mouth and drinks blood fom inside. Eventually becomes small (like mosquito) and enters the host to consume the rest of body fluids and life. It seems to be based on giant marsupials, which have skulls with a large opening in the forehead - like in the skull of a (placental) mammoth suggesting a single large eye.



Figure 4. The Papinijuwari of Australia. Drawing by P. Jandáček, Nov. 2017, based on descriptions of Mudrooroo (1994)

By the time humans reached Australia they only had their ancestors' stories about the one-eyed giant Ogres and giant marsupials with shorter trunks and the robust confirmation of an elephant.

Skull of an elephant has a large eye-socket-like opening in the center of the forehead, Figure 5.

The Cyclops, Figure 6, are known from the Greek Mythology. Like the Australian Papinijuwari - the Cyclops is a One-Eyed Ogre. Likely this is based on the fact that there is a large opening in the skull of elephants/mammoths, which looks like an eye socket.

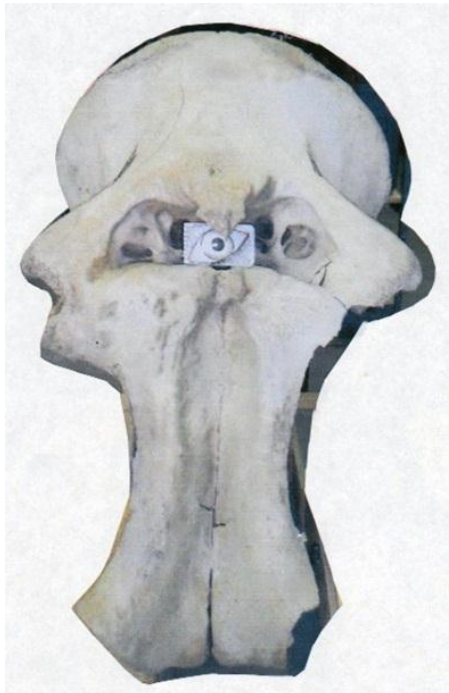

Figure 5. Skull of a mammoth suggesting a Single Large Eye of a cyclops and the omniscient eye inside of a triangle. Photo by P. Jandáček, July 2016 at the Beringia Museum in Whitehorse, Yukon, Canada 


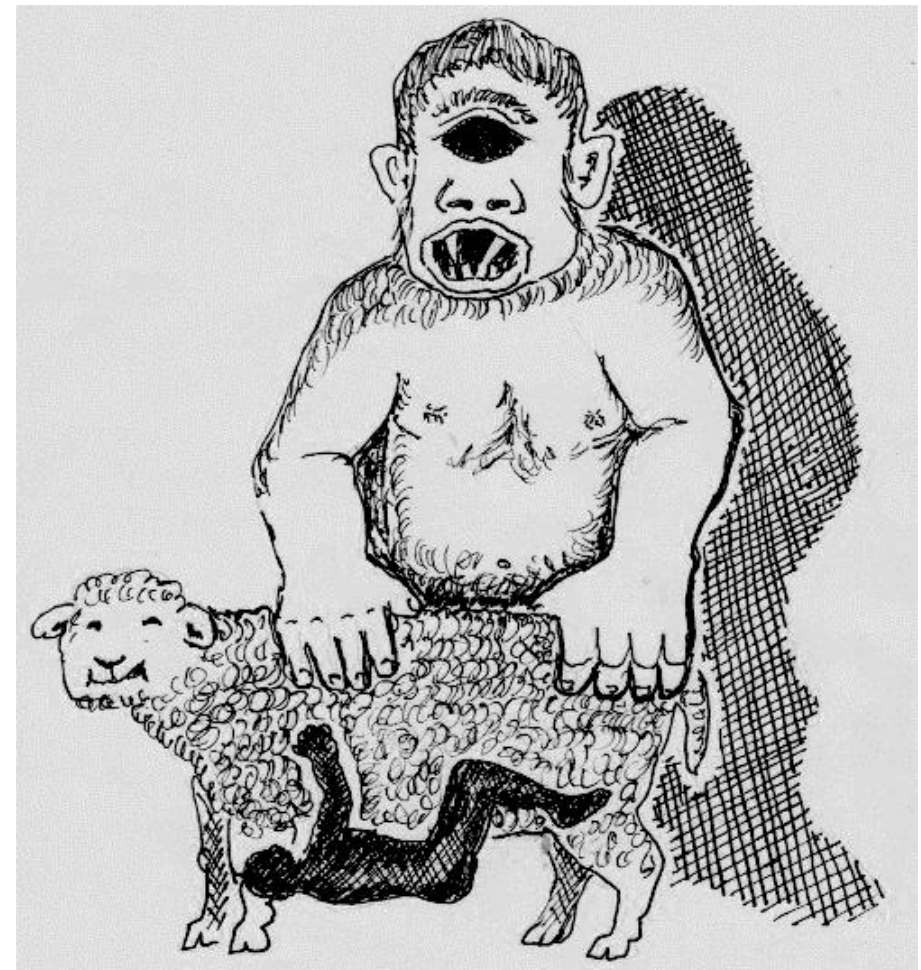

Figure 6. Cyclop. Drawing by P. Jandáček Nov. 2017

Palorchestes preserved in Aboriginal Mythology as Kian prati or Bunyip. Giant Marsupials of Australia lived at the same time as Stegodon on Flores Island, Indonesia, 2,283 km across the Timor Sea. Stegodons (miniature elephants of about $500 \mathrm{~kg}$ ) were very large game for the tiny Homo floresiensis, Figure 7.

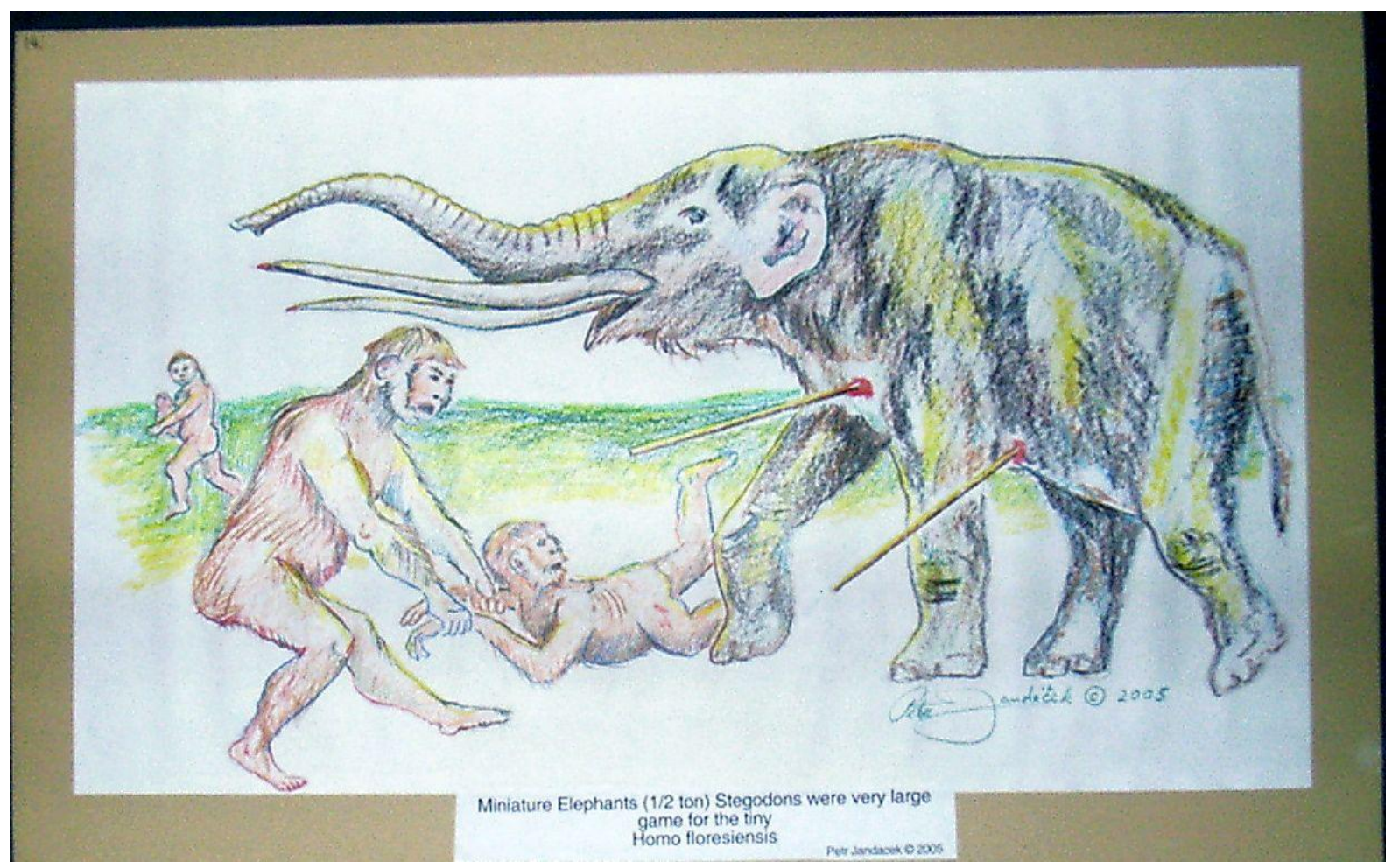

Figure 7. Miniature Elephants (500 kg) Stegodons were very large game for the tiny Homo floresiensis. Drawing by P. Jandáček, 2005

Jandáček observed in Zimbabwe that native people burn dried elephant dung to repel tsetse flies, mosquitos and other flying and biting insects. This is yet another observed link between elephants, smoke and insects. 
The North American mythology about the Stiff-Legged Bear - Katci-to-wack'w, Figure 8, tells that it has skin, which is Pachyderm, resistant to arrows. It is believed by many experts, e.g. Strong (1934:81) to be based on the mammoth and the mastodon.

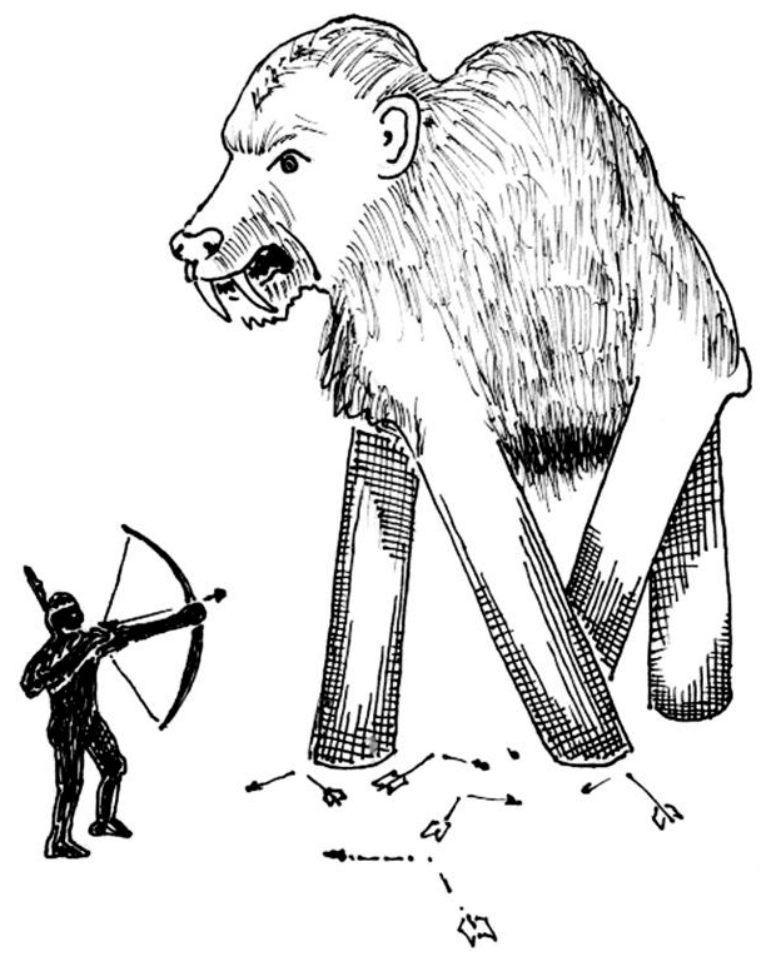

Figure 8. Stiff-Legged Bear - Katci-to-wack'w ${ }^{\prime \mathbf{w}}$ Drawing by P. Jandáček Nov. 2017

Even in western Slovenia there is a remote similarity in oral tradition. On the mountain pasture Sleme $(\sim 1400 \mathrm{~m}$ above the sea level) there was the tradition to make the boys afraid of the ogress Štefenajka (pron. Shtefenayka) in the manner that when the boy comes to Sleme for the first time, Šefenajka will come from beyond a huge rock and mount him. If he would not be able to carry her three times around the dairy abode he would have to eat bread spread with her snivel (Šavli, 1971). The snivel detail relates to the description No. 7 above. In the vicinity of the mountain pasture Sleme there are observed traces of human activity since Mesolithics on.

\section{Discussion}

Around the world there are many Mythological Beings, which are evidently based on the mammoth (or other related elephants). The giant size and human-like anatomy (especially of the females) makes mammoths the perfect candidates for supernatural anthropomorphic beings.

Female elephants, Figure 9, have "breasts" located in the thorax region and prior to coitus females have a virginal hymen as do human maidens. Such anatomical details remain important in Abrahamic religions such as Judaism, Christianity and Islam. The genitalia of female elephants are oriented towards the front (as in humans) instead of towards the back as in most quadrupeds. This is another anthropomorphic feature.

Mammoths and other elephants have a large opening in the middle of the forehead of the skull, which suggests that they had a single large eye as in a Cyclops. In Australia giant marsupials had a similar feature - giving rise to Papinijuwari the One-Eyed monster. 


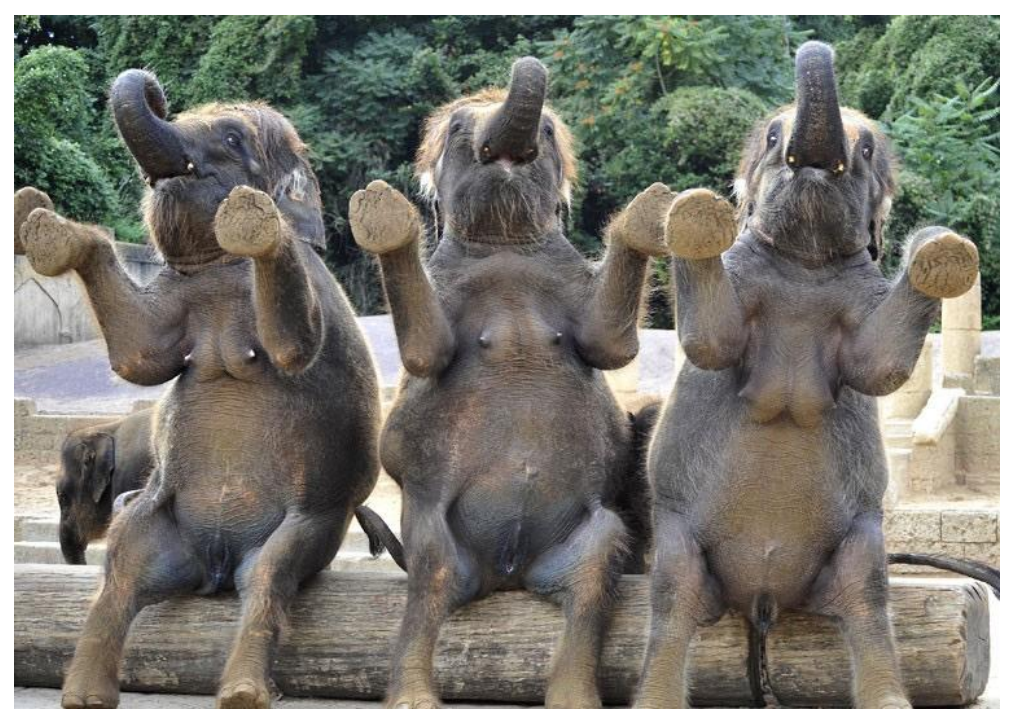

Figure 9. Sitting female elephants. (https://www.shutterstock.com/search/female+elephant)

Deliberate elongation of human skulls as well as trepanning (trephining) may be an attempt to make skulls more mammoth-like, Figure 10.

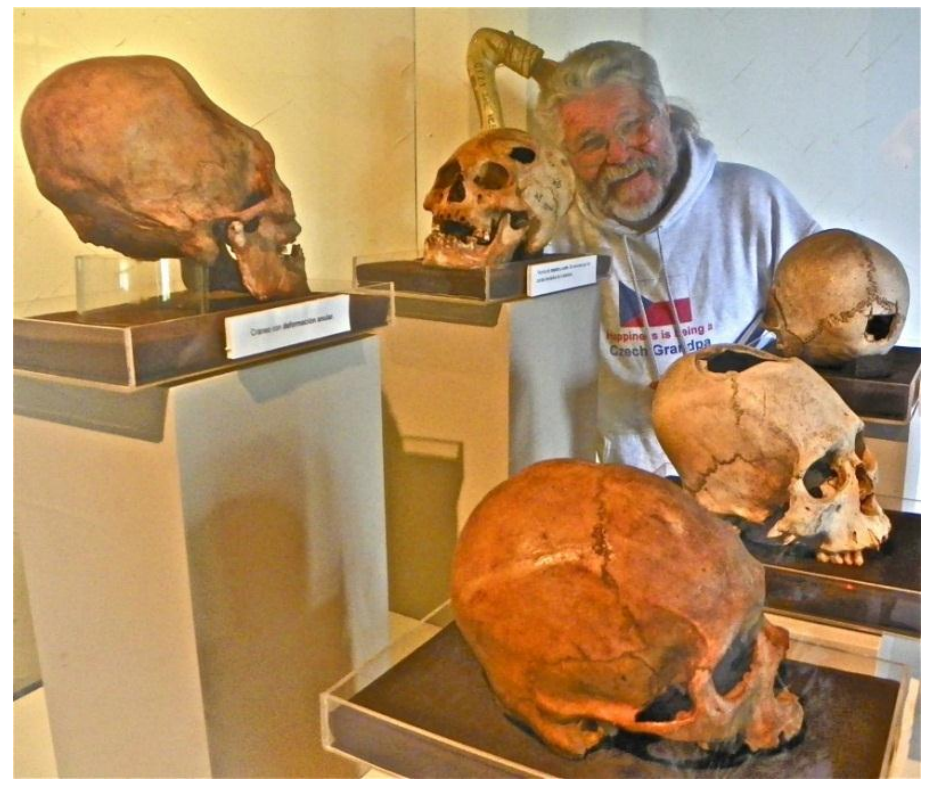

Figure 10. Deliberately elongated human skull. Behind: P. Jandáček. Photo by Louise Jandacek, Nov. 2011 in Cusco, Peru Museum

The belief in the transfiguration between elephantine ogres and mosquitos may be spawned by the timing of events. The hunt and butchering of mammoths would attract mosquitos and flies to a feast of blood and flesh. Clouds of insects would come and disperse and suggest to the people that the biting pests with the proboscis were a reincarnation of the giant proboscidean.

It is also possible that the primordial experience with mammoths and mosquitos merged in later times, when the mammoths were already extinct, with the struggles between the aboriginal inhabitants and the intruding newcomers. First this happened with the agriculturists (after about 7,500 years ago, having Y Chromosome haplogroups G2a, R1a, J, E), later with the Y Chromosome haplogroup R1b people (after about 4,500 years ago in western Europe and southern Scandinavia) or N1a people (after about 3,000 years ago in northeastern Europe). In remote, less fertile and colder areas only the very strong persons survived as hunters and gatherers. Physical size declined amongst agriculturalists. The farmers would view hunters and gatherers as robust and threatening.

A similar development may had led to the tradition about the Amerindian Stiff Legged Bear - Katci-to-w $\alpha$ ck $^{\prime w}$. Whereas the extant northern Algonkians do not understand it mammoth-like but bear-like, after living millenia devoid of 
mammoths but in presence of bears, they transmitted the mammoth-based traditions to the bears.

This and the Śtefenajka case indicate that the mammoth based Ogres stories were much more widespread than considered till now, but on changing the environment and influence of other cultures they are largely transformed or forgotten.

\section{Acknowledgement}

Valuable discussions and providing the $\check{S} t e f e n a j k a$ case by A. Perdih is thankfully acknowledged.

\section{References}

Dsonoqua. In Eberhart, G. M. (2002). Misterious creatures: a guide to cryptozoology. Santa Barbara, CA: ABC-CLIO, p. 149. https://books.google.com/books?id=z9gMsCUtCZUC\&pg=PA149\&lpg=PA149\&dq=f.+boas+on+tsonoqua\&sourc e=bl\&ots=JVQvlmlh2R\&sig=hPF4FGus_e3fp6ZjL3iYSl4fx0c\&hl=en\&sa=X\&ved=0ahUKEwiejfLN5aLXAhVB 6mMKHRAJDzwQ6AEISTAE\#v=onepage \&q=f.\%20boas\%20on\%20tsonoqua $\& \mathrm{f}=$ false

Jandáček, P. (2013a). "Slon" in the language of mammoth hunters. Root-words for elephant. Part I. Why are the words for ELEPHANT so similar across EURASIA? Proceedings of the Academy of DNA Genealogy, 6, 1884-1888.

Jandáček, P. (2013b). "Slon" in the language of mammoth hunters. Root-words for elephant. Part II. SLON in the minds of Gravettien/Pavlovian/Kostienkian and other Mammoth Hunters. Proceedings of the Academy of DNA Genealogy, 6, 1889-1895.

Jandáček, P. (2014). "Slon" in the language of mammoth hunters. Proceedings of the Twelfth International Topical Conference Origin of Europeans. (pp. 109-118). Ljubljana: Založništvo Jutro.

Jandáček, P. (2017). SŁəD (SLON) was apparently the Trans-Eurasian word for mammoth/elephant. Proceedings of the $14^{\text {th }}$ International Conference "The Origins of Slovenes and Europeans". (pp. 93-98). Ljubljana: Založništvo Jutro.

Jandáček, P., \& Perdih, A. (2017). Words for the Animal Elephant/Mammoth in Relation to the DNA Genealogy Data. Advances in Anthropology, 7, 251-272. https://doi.org/10.4236/aa.2017.74014

Lecouteux, C. (2016). Encyclopedia of Norse and Germanic folklore, mythology, and magic. Rochester VE: Inner Traditiones International.

https://books.google.com/books?id=vmAoDwAAQBAJ\&pg=PT329\&lpg=PT329\&dq=mythological+stallo\&sourc e=bl\&ots=STmOCKPZ3D\&sig=1B14-6gdzCTI8mSPqIVlgBR8u3k\&hl=en\&sa=X\&ved=0ahUKEwisp-_j66LXAh VI3GMKHUrJB-QQ6AEIWjAM\# $\mathrm{v}=$ onepage $\& \mathrm{q}=$ mythological\%20stallo \&f=false

Mudrooroo. (1994). Aboriginal mythology: An A-Z spanning the history of the Australian Aboriginal people from the earliest legends to the present day. (p. 37). London: Thorsons. ISBN 978-1-85538-306-7.

Šavli, J. (1971). Ljudsko besedje na Tolminskem, Pravljica o Štefenajki [Oral tradition in the area of Tolmin, Slovenia, Fairy tale about Shtefenayka]. Novi list, 29(7). 1971.

Strong, W. D. (1934). North American traditions suggesting a knowledge of a mammoth. American Anthropologist, 36, 81.https://doi.org/10.1525/aa.1934.36.1.02a00060

http://nordligefolk.no/hjem-2/fortellinger-sagn-og-myter/stallo/?lang=en

http://www.revolvy.com/main/index.php?s=Dzunukwa

https://www.shutterstock.com/search/female+elephant

\section{Copyrights}

Copyright for this article is retained by the author(s), with first publication rights granted to the journal.

This is an open-access article distributed under the terms and conditions of the Creative Commons Attribution license which permits unrestricted use, distribution, and reproduction in any medium, provided the original work is properly cited. 